Review

\title{
Sustainable Land Management in Mining Areas in Serbia and Romania
}

\section{Vesna Popović $^{1, \dagger}$, Jelena Živanović Miljković ${ }^{2, \dagger, *}$, Jonel Subić ${ }^{1, \dagger}$, Andrei Jean-Vasile ${ }^{3, \dagger}$, Nedelcu Adrian ${ }^{3, \dagger}$ and Eugen Nicolăescu ${ }^{4, \uparrow}$}

1 Institute of Agricultural Economics, Volgina 15, Belgrade 11 000, Serbia;

E-Mails: vesna_p@iep.bg.ac.rs (V.P.); jonel_s@iep.bg.ac.rs (J.S.)

2 Institute of Architecture and Urban \& Spatial Planning of Serbia, Bulevar kralja Aleksandra 73/II, Belgrade 11 000, Serbia

3 Faculty of Economic Sciences, Petroleum-Gas University of Ploiesti, B-dul Bucuresti, No.39, Ploiesti, Prahova 100680, Romania; E-Mails: ajvasile@upg-ploiesti.ro (A.J.-V.); nedelcuadrian56@yahoo.fr (N.A.)

4 Department of Finance, Banking, and Accountancy, Dimitrie Cantemir Christian University, Bucharest 030134, Romania; E-Mail: eugengnicolaescu@gmail.com

$\dagger$ These authors contributed equally to this work.

* Author to whom correspondence should be addressed; E-Mail: jelena@iaus.ac.rs; Tel.: +381-11-3207-334; Fax: +381-11-3370-203.

Academic Editor: Marc A. Rosen

Received: 18 June 2015 / Accepted: 10 August 2015 / Published: 26 August 2015

\begin{abstract}
The paper analyzes the impacts of mining activities on sustainable land management in mining areas in the Republic of Serbia and Romania and discusses the main challenges related to the management of these issues in legislation and practice. Particular attention is paid to land disturbance, mine waste management and land reclamation, as well as access to land for mining purposes, the transfer of mining royalties and the partnerships of the mining industry, governments, communities and civil society for sustainable mining. Both governments are willing to provide the adequate role to mining in strengthening the national economies, but they face numerous constraints in this matter. Sustainable mining practices and consistent implementation of the mining for the closure planning approach, within an improved legislative framework and in cooperation with stakeholders at all levels, create conditions for the development of creative, profitable, environmentally-sound and socially-responsible management and reuse of mine lands.
\end{abstract}


Keywords: sustainable land management; mining; mining waste management; land reclamation

\section{Introduction}

Land performs many key environmental, economic, social and cultural functions that are vital for life. These functions are generally interdependent, and the extent to which land performs them is strongly related to sustainability [1].

According to the World Commission on Environment and Development definition, sustainable development is the type of development that meets the needs of the present without compromising the ability of future generations to meet their own needs [2]. The objective of sustainable land management (SLM) is to harmonize the complementary goals of providing environmental, economic and social opportunities for the benefit of present and future generations while maintaining and enhancing the quality of land resources [3].

The need for urgent action to reverse land degradation and to achieve a land degradation-neutral world in the context of sustainable development is stressed in the UN Rio+20 conference [4]. The 2011 Roadmap to a Resource Efficient Europe [5], as a part of the Europe 2020 Strategy for smart, sustainable and inclusive growth [6], promotes resource-efficient development and forces the EU policies to consider, by 2020, their direct and indirect impacts on land use, striving for the goal of no net land take by 2050 [7]. These approaches comprise the development of land policy and planning based on inter-sectoral policy coherence, strengthening of institutions and interactive stakeholder participation.

Much of the impact from mining is directly or indirectly linked to land. The exploitation of mineral resources, especially surface mining, causes numerous negative environmental externalities and socio-economic impacts, e.g., land use changes, ecosystem disturbances, watercourse relocation and a decrease in ground water level, changes in infrastructure networks, non-balanced industrial development, resettlement and changes in the economic and social structure of the local population, etc. [8]. Positive impacts can also occur, such as increased conservation activities and water quality management $[9,10]$. Managing the impacts of changes in land use, i.e., mitigating the negative impacts and enhancing the positive impacts, is an important sustainable development goal that poses a challenge for mining companies and regulatory agencies [11].

The key to success in the role of minerals in sustainable development is in the utilization of this resource as a platform for achieving economic diversification, growth and broad development goals, while maintaining social stability and protecting environmental integrity [12].

Regarding sustainable mining practice, the focus is on how mining companies, operating in a responsible and sustainable manner, can contribute to sustainable development at all levels. Mining companies are expected to create and share value and responsibility across a complex set of economic, environmental and social issues in the sustainable world, and good environmental and social practice is considered a part of the company's competitive advantage [13]. Advances in technology help operations to extract lower-grade ores than those just a few decades ago, to increase productivity and to reduce costs. Operations are meeting stricter environmental requirements for lower emissions, energy, waste and water use. Rehabilitation standards are higher and costlier to meet, and management responsibility 
has longer terms. Companies need to actively plan how to reduce the environmental impacts of their operations to secure and maintain their license to operate [14].

Beyond the legal license, the concept of a social license to operate (ongoing approval within the local community and other stakeholders of both mining companies and their projects) has been widely recognized by the industry as an essential attribute of success [15]. The social impact assessment (SIA), strengthened by the concept of free, prior and informed consent (FPIC) as an overarching philosophy, and the impact and benefit agreement (IBA), as well as the social impact management plan (SIMP) as the outputs, emerges as a powerful tool for assessing, managing and monitoring the social impacts during implementation and as a tool for a proactive response to changes across the lifecycle of developments [16-18].

Rather than simply regulating, the governments tend to improve industry behavior by encouraging transparency and boosting civil engagement. Policies are formulated to promote shared value for industry, governments and civil society, and the partnerships of these stakeholders serve to maintain and manage shared-value opportunities [14].

Being highly dependent on the imports of raw materials, the EU in the Athens Declaration on sustainable access to resources (2014) [19] asks the member states to upgrade their minerals policies, land use planning and legal framework to secure sustainable access to their domestic mineral resources. National governments were in particular encouraged to establish adequate regulatory frameworks to secure mineral deposits of public importance that facilitate investments, but also to ensure that mineral property rights are sufficiently protected. In land use planning, the existence of mineral deposits should be taken into account in the development of urban, highly populated or industrial areas, avoiding potential conflicts, on the basis of national/regional mineral strategies.

A sustainable minerals policy needs to: facilitate the transformation of natural mineral capital into built physical, economic, environmental or social capital of equal or greater value; ensure that environmental and negative social impacts of mining are minimized and their costs incorporated into production functions; require transparency and information sharing; reconsider the allocation of rights and the availability of resources across generations; address benefit/risk trade-offs from the perspective of multiple stakeholders and to create contingency plans that will ameliorate the effects of mineral market booms and busts; and be correlated and consistent with other governmental policies [20,21].

The aim of a land use policy for minerals should be, ultimately, to ensure fair and equal consideration of all potential uses of land, including the eventual extraction of raw materials. Land use planning for minerals should be long-term and undertaken at a national or regional level. A national planning framework can help to ensure that minerals are given due weight in the land use planning process; it is therefore recommended as the best practice in appropriate national circumstances [22].

Mining operations, except mining waste, which is regulated at the EU level [23,24], are a matter of concern of the national administrations and, consequently, regulated at the national level. Mining law usually defines general principles and key rules and procedures for mining explorations and exploitation projects (regulatory authorities, property rights, fees and taxes, environmental, health and safety obligations, mine closure and land rehabilitation). 
In practice, all of these efforts are far from consistent within each company, let alone across the entire industry. The mining costs have escalated mainly due to poor planning, low investments in technology innovation, inefficient operations and rising prices of water and energy. Disputes among mining companies and local communities and governments have posed a particular challenge, causing about \$25bn worth of projects being delayed or suspended worldwide [25].

A new roadmap for collaborative, long-term sustainable mining should be based on three pillars: shared purpose during and after the mine's operation, flourishing ecosystems, with a reduced environmental footprint of every mining activity as the first step, and achievement of long-term sustainable prosperity for the communities and nations in which the mining companies operate, as well as for the companies themselves [26].

\section{Mine Land Management in Legislation and Practice: Production Capacities and Potentials in Brief}

Mining activities have a long-standing tradition in the Republic of Serbia and Romania. The restructuring of the mining sector, transition and privatization in the last two decades have brought many mines to closure or to operating with reduced capacity, particularly in Romania, where by 2004, production had been terminated in 344 unviable mines, and the process of mine closure is still ongoing [27].

In recent years, with the rising prices of copper and noble metals on the world market and enlargement of the EU list of important and critical raw materials for the EU economy [28], there is growing interest of investors for the mining sectors in both countries.

\subsection{The Republic of Serbia}

Geological exploration and exploitation of mineral resources in the Republic of Serbia are today taking place in 105 exploration and 250 exploitation fields [29].

Coal mining in Serbia is carried out in: two large lignite basins with surface exploitation: the mining basin (MB) Kolubara (open pit Field B, Field D, Tamnava-West Field and Veliki Crljeni) and MB Kostolac (open pit Drmno), within the public company Electric Power Industry (EPS) of Serbia; underground hard coal mines (seven) and lignite mine Lubnica, within the Public Enterprise for Underground Coal Exploitation Resavica, in restructuring; and underwater lignite mine Kovin at the Danube.

About 100 million $\mathrm{m}^{3}$ of overburden and over 38 million tons of lignite per year are exploited by surface mining, over 220 thousand tons of lignite by underwater exploitation and up to 660 thousand tons of hard coal and minor quantity lignite in underground mines [30]. According to EURACOAL data for 2012, the resources of hard coal amount to 184 million tons, and reserves amount to 176 million tons, while lignite resources amount to 5363 million tons, while reserves amount to 3660 million tons [31].

Oil and gas production takes place on 42 oil fields with 650 wells, with an annual production of 1.2 million tons of oil and 562 million $\mathrm{m}^{3}$ of natural gas [32]. The state oil company Petroleum Industry of Serbia (NIS), majority-owned by GazpromNeft (St. Petersburg, Russia), is the only company engaged in the exploration and production of oil and gas. 
Shale oil reserves are estimated to be at about 4.8 billion tons and are found mostly in the area of the Aleksinac coal basin (about two billion tons) [30]. The exploitation is not done, but it is envisaged in the Strategy of Mineral Resources Management until 2030 (SMRM).

The exploitation of copper and associated metals in copper ores - lead, zinc, gold and silver - takes place in majority state-owned Mining and Smelting Combine Bor (RTB Bor Group), in copper mines in Bor and Majdanpek. According to RTB Bor Group data, during century-long mining activities (up to 2011), more than 750 million tons of copper ore have been excavated; approximately 3.35 million tons of copper, 155.5 tons of gold and 971 tons of silver have been produced; and more than 1820 million tons of overburden have been removed. Certified geological reserves amount to 1.38 billion tons of ore containing about 5.1 million tons of copper, 202 tons of gold and 1477 tons of silver. Confirmed reserves, with the average annual exploitation of 26 million tons of ore, guarantee copper production for the next 50 years [33].

Four lead and zinc mines are active; they are privately owned and produce $10 \%-12 \%$ of the volume of two decades ago, when there were over ten active lead and zinc mines [34]. The balance ore reserves of lead and zinc amount to about 6.22 million tons and off-balance ore reserves about 4.2 million tons, containing about 0.34 million tons of lead and about 0.35 million tons of zinc [30]. In 2010, the production of zinc was 2600 tons and the production of lead 1800 tons [35].

There is also significant potential for the exploitation of antimony, lithium, nickel, cobalt and molybdenum [30].

Non-metallic minerals in exploitation are clays, quartz raw materials, barite, gypsum and anhydrite, zeolites, feldspars, diabase, ornamental and building stone. Borates, phosphates, magnesite and fluorite also have good prospects for exploitation [30]. The privatization process gave the best results in this segment of mining, and the future production growth will depend on the development of the industry and construction in the country.

The SMRM predicts that the production of the mining sector will increase from the current $2 \%$ to over $5 \%$ of GDP in 2020, with investments of over 3.5 billion euros, which would bring revenues of three billion euros.

\subsection{Romania}

Romania has significant mineral resource potentials, especially in oil and natural gas, including shale gas deposits, lignite and hard coal, gold, silver, copper, lead, zinc, uranium and salt, as well as a larger number of other non-metallic minerals.

According to the draft of Energy Strategy 2015-2030, with an average annual production of 4.2 million tons, Romania is the fourth-largest oil producer in the EU and the fifth-largest in Europe. The annual production of natural gas totals to 11 billion $\mathrm{m}^{3}$. Proven oil and gas reserves amount to 60 million tons and 150 billion $\mathrm{m}^{3}$ [36]. OMV Petrom (Bucharest, Romania), a member of Austria's OMV Group, is the major domestic crude oil producer and one of the two leading natural gas producers in the country, after the majority state-owned Romgaz (Mediaş, Romania).

Romania has one of the biggest shale gas reserves in Eastern Europe in the amount of 1.4 trillion $\mathrm{m}^{3}$ [37]. After five years of public protests, ban and re-approval, Chevron withdrew from exploration in Romania in 2015, as drilling results fell short of expectations, despite large investments. The recent Energy Watch 
Group study (2015) indicates that the costs and the environmental damage produced by fracking are out of proportion to the amount of raw materials extracted [38].

Coal production has almost halved during the 20 years of the transition and restructuring period [39]. In 2012, it amounted to 34 million tons. Hard coal reserves and resources are estimated at 2446 million tons, of which 252.5 million tons are commercially exploitable, but only 11 million tons might be economically recoverable. Reserves of lignite total to 280 million tons, with a further 9640 million tons of resources [31].

Hard coal is exploited within two separate operating units under the majority state-owned Hunedoara Energy Complex (CNH SA Petrosani). One unit produces about 40 thousand tons monthly in three coal mines in the Jiu Valley (Uricani, Paroseni and Petrila) that will be closed by 2018, following the EU Council Decision on state aid to facilitate the closure of uncompetitive coal mines [40]. The other unit operates four coal mines in MB Petrosani (Lonea, Livezeni, Vulcan and Lupeni) without state aid, with an annual production of 1.5 million tons. The annual production of lignite in 2012 amounts to 32.1 million tons. The majority state-owned Oltenia Energy Complex (Targu Jiu, Romania) is the leader in lignite production [39].

Despite significant reserves of non-ferrous metals, Romania currently exploits relatively small quantities of copper, gold, silver, lead and zinc ores. Besides silver, the production is highly reduced compared to the beginning of the previous decade. According to World Mining data, in 2012, the production of copper amounted to 9.5 thousand tons, gold $500 \mathrm{~kg}$, silver 18 thousand tons, lead 5.5 thousand tons and zinc 8.4 thousand tons [35].

The state-owned company Cupru Min holds the largest part of Romania's copper reserves (the Rosia Poieni open pit mine with estimated mineral reserves of over one billion tons) [41]. Lead and zinc (associated with copper, antimony, bismuth, cadmium, gold and silver) are exploited at underground mines in Baia Mare, Baia Borsa, Certej and Rodna counties [42]. Romania has the largest gold reserves in Europe (760 million tons of gold-silver ores, of which 40 million tons are in 68 gold deposits of Transylvania's Golden Quadrilateral, in the Apuseni Mountains, comprising the Rosia Montana, Bucium, Baia de Aries, Almas, Brad and Sacaramb mining areas) [43].

Non-metallic industrial minerals in exploitation (2012 data) are bentonite, feldspar, gypsum, kaolin, graphite, salt and talc [35]. The mines of these minerals are located throughout the country, and the privatization in this part of the mining sector was quite successful.

The uranium deposit in Crucea, in Suceava County, has been exploited for 30 years and will be closed in 2015 after being exhausted [44].

According to [45], mining and quarrying accounted for $3.5 \%$ of the value of industry production in 2011 (coal and lignite $0.6 \%$, oil and natural gas $1.8 \%$, metal ores $0.1 \%$ and other mining and quarrying and support services $1.0 \%$ ).

\section{Mining Land Management in the Republic of Serbia and Romania: An Overview of Selected Issues}

Mining companies are making efforts to minimize the footprint of their activities throughout the mine life cycle, including post-mining site rehabilitation. Mining revival and development need updated legislation and clear political support, as well as better understanding and cooperation between the government, investors and local communities and civil society. 
The mining for closure planning approach includes related environmental, social and economic issues, as well as the participation of stakeholders, particularly in consideration of land rehabilitation objectives [46]. Mine rehabilitation and closure plans are required by regulatory agencies around the world and are often a component of the environmental impact assessment process practiced in over 100 countries $[47,48]$.

Land disturbance, waste disposal and post-mining site rehabilitation, as well as access to mineral deposits and land acquisition for mining purposes, the transfer of mining royalties and public participation are the main issues faced by the industry, governments, investors, communities, civil society and other stakeholders. The status and challenges related to the management of these issues in legislation and practice in Serbia and Romania are discussed below.

\subsection{Land Use Change}

Despite the fact that mining has a small share of a country's total land use, conflict can arise at the local level where mining is perceived as competing with agriculture and livestock grazing or other land uses $[49,50]$.

The Serbian Strategy of Mineral Resources Management until 2030 (SMRM) envisages an increase of demand for coal to 48 million tons by 2025. In order to increase the production of lignite, EPS expands the existing and opens new open pits.

MB Kolubara is surrounded by dense population, fertile agricultural land and developed infrastructure. Termination of the exploitation in this basin is expected for the period 2055-2060, and a rough estimation is that in the period 2020-2060, production will be conducted on the three open pits (Radljevo, Tamnava-West Field and Field E). There is a plan for the acquisition of 4694 ha for mining and an energy-industrial complex, while 3411 hectares of degraded land will be reclaimed until 2020 [51].

MB Kostolac is also located in an agricultural area and includes Viminacium, one of the most significant archaeological sites in Serbia. For the expansion of the open pit Drmno, in the period of 2010-2022, there are plans for the acquisition of 953.4 ha, which includes 833 ha of fertile agricultural land and about 1180 ha throughout the open pit life cycle (up to 2054). The exploitation of the western lignite deposit Dubravica will require over 2000 ha, resettling parts of three villages and reconstruction of the infrastructure systems. The loss of agricultural land will be partially offset by reclamation (1200 ha by 2022) [52] (Figures 1 and 2).

The SMRM envisages a rise in copper production by three times, and the production of lead and zinc will double by 2020. The government seeks strategic partners to open two new open pits and to activate the underground copper mine "Borska reka" in Bor for the new smelter capacity of 80 thousand tons of copper, as well as the underground gold mine "Čoka Marin" in Majdanpek. 


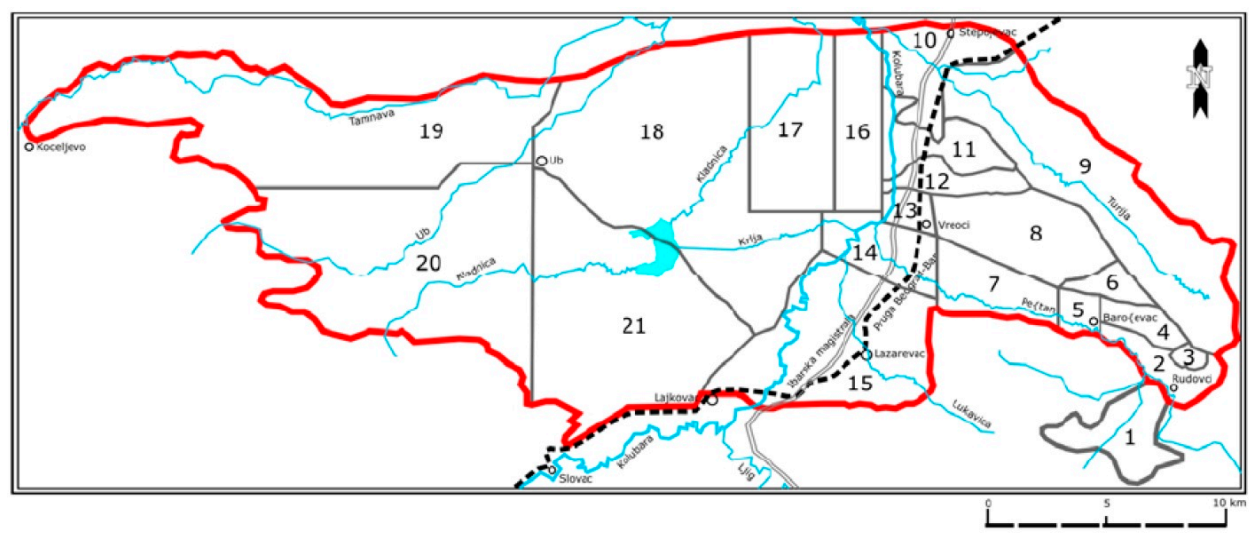

Figure 1. Mining basin (MB) Kolubara: open pits and potential areas for exploitation. 1, Field Kruševica; 2, Field Rudovci; 3, Field A; 4, Field B; 5, Field C; 6, Field Baroševac; 7, Field E; 8, Field D; 9, Field Turija; 10, Field Stepojevac; 11, Field Veliki Crljeni; 12, Field Volujak-Vreoci; 13, Field G; 14, Field F; 15, Field Šopić-Lazarevac; 16, Tamnava-East Field; 17, Tamnava-West Field; 18, Field Radljevo; 19, Field Trlić; 20, Field Zvizdar; 21, Field Ruklade. Source: [53].

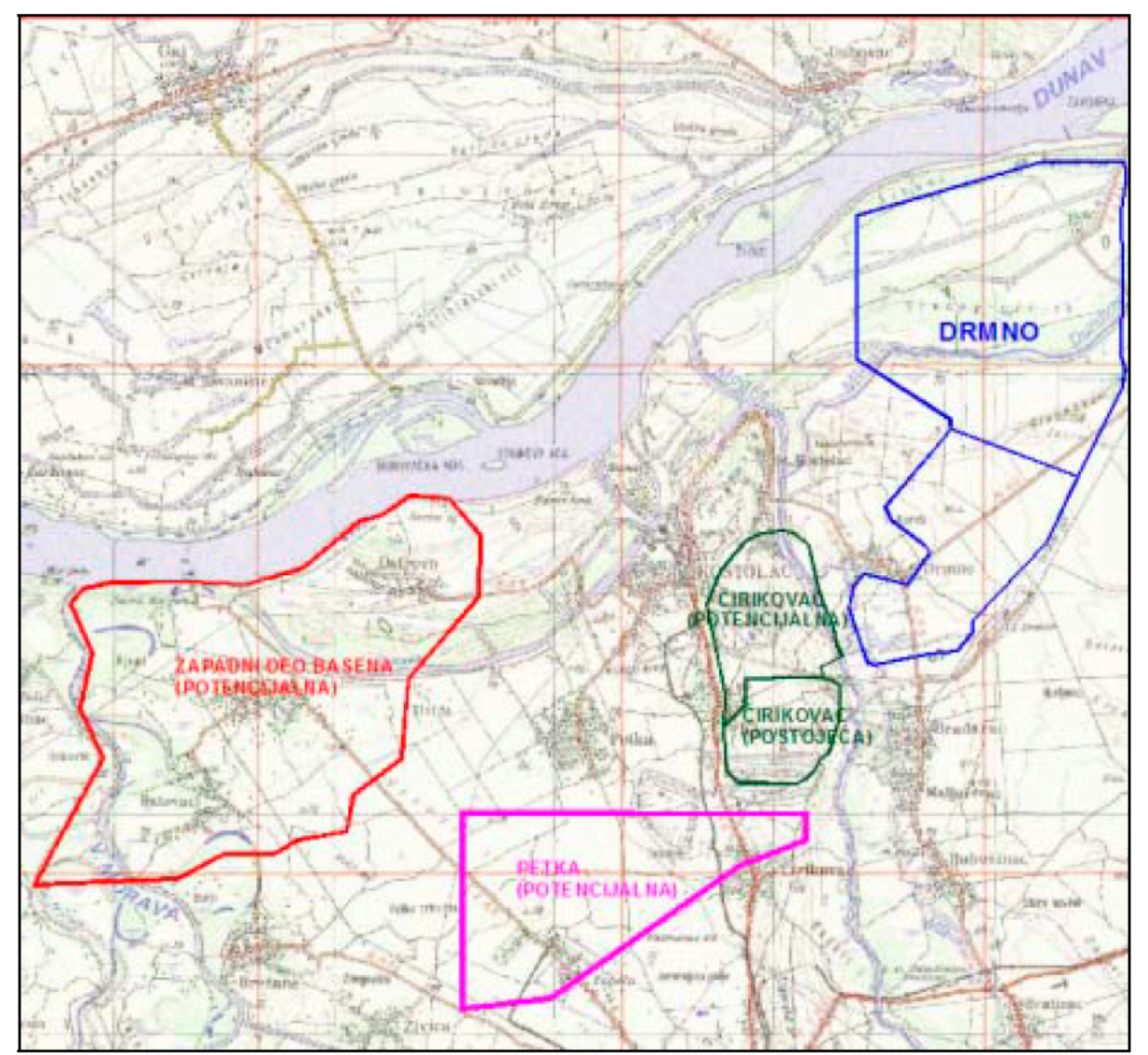

Figure 2. MB Kostolac: open pits (marked with the blue line) and potential areas for exploitation (red, magenta and upper green line). Source: [52].

In July 2013, the government of Romania adopted the national plan for strategic investment and job creation in five investment fields, including seven projects in the mining sector (among them Rosia Montana and Certej open pit gold mines) [54]. 
The Rosia Montana mining project comprises 1346 ha to be exploited, of the 2388 ha for which the company owns a license, and 300 ha covered by a tailings management pond of heavy metals and cyanide, which will permanently endanger more than 6000 people from the neighboring areas, 2064 private properties relocated, 975 houses torn down, out of which 41 houses are considered national heritage sites, as well as seven churches, 11 cemeteries relocated and only 634 jobs created over a period of 17 years [55].

The Certej mining project, within a 16-year duration period, involves deforestation, soil uncovering, an open pit, two huge waste dumps and the use of cyanides to obtain gold, as well as building two tailings dams over 63.6 ha. The project area of 456.2 ha is currently covered by: forests in 187 ha, meadows in 30.7 ha, arable fields in 5.3 ha and residential areas in 18.7 ha. Certej is located within the Natura 2000 Special Protection Area (SPA) site ROSPA 0132 [55].

There are also considerations about small-scale cyanide gold mining. According to Marincea, in the new 50 deposits identified, the use of the cyanide-based preparation technology "would generate no less than 2900 ha with cyanide waste" [43]. The mining area is usually located on forest lands, pastures and meadows, often in protected areas and/or areas dedicated to agriculture and rural tourism [43].

A new uranium exploitation site is planned for opening in Neamt County, with annual exploitation of 124 thousand tons for the needs of the Cernavoda nuclear plant [44].

Land use change associated with the direct and offsite footprints of mining causes environmental and social impacts [11]. Although systematic analysis of mining land use dynamics is not included in this overview, it is clear that land use acquisition for mining purposes reduces the area of agricultural and forest land in both countries, but also leads to intensive land abandonment.

The reasons for leaving agricultural production in the vicinity of large open pit coal mines in Serbia are changes in the socio-economic structure of the population due to higher earnings in the mining sector, resettlement and the migration to the nearby big urban centers and abroad [56,52]. In Romania, the exploitation of gold-silver and polymetallic ores in the former mining regions discourages the development of agriculture and rural tourism, bearing in mind the serious environmental legacies (see below) and the negative perception of food consumers and tourists regarding new potential pollution of soil, water and air and disruption of ambient values.

\subsection{Mining Waste Management}

Overburden and waste rock piles and dumps, tailing ponds, oil and gas wells and produced water ponds occupy considerable areas of land, especially large open pit mines. Most mining wastes, such as overburden, are inert solid materials; they do not represent a significant pollution threat to the environment, but they do cause erosion, fertile land loss and ecosystem and landscape disruption. However, other fractions, in particular those generated by the non-ferrous metal mining industry, may contain large quantities of dangerous substances (inherently present in the ore or added during extraction) and generate acid or alkaline drainage contaminating soil and waters [57].

The management of tailings refers to serious risks (dam failures) and environmental, often cross-border, impacts (dust, tailings dam seepage, dam wall failure or direct disposal of tailings into waterways). Technological advances and changes in regulations have resulted in significant improvement in tailings and overall mining waste management practices over the last two decades [58-60]. 
Due to the lack of budget funds, a large number of abandoned mines have been waiting for rehabilitation for decades, as well as mines owned by private business firms in bankruptcy (and unable to take on appropriate rehabilitation measures). In the Vojvodina province alone, according to the recently established cadastre of abandoned mines, there are 217 abandoned mine and quarries [61]. According to UNEP studies of reducing environment and security risks from mining in the Western Balkans, the hotspot sites with the potential transboundary risk via waterways (Drina, Sava, Danube) in Serbia were principally associated with antimony mining, processing and smelting, lead and zinc mining, processing and smelting and copper mining, processing and smelting $[46,62]$.

Rehabilitation of old open pits in the Bor mine was done by making the open pit "RTH" backfilled with tailings and open pit Bor backfilled with overburden from open pit "Veliki Krivelj". In 2012, the government cancelled the remediation of overburden dumps and tailing ponds in Bor and Veliki Krivelj, provided by the World Bank Project P092999, since national experts advocate re-mining, having in mind that mine waste has a relatively high concentration of metals due to earlier applied inefficient metal extraction processes [63].

In 2012, the Petroleum Industry of Serbia (NIS) (Novi Sad, Serbia) began implementing the plan of oil- and gas-produced water ponds' rehabilitation by 2016, with a special focus on 50 of those with more than $5 \%$ of hydrocarbons, which, not being repaired for decades, pollute the air and threaten the land and waters. During 2011-2012, NIS remediated and reclaimed 80 produced water ponds in Vojvodina province and returned the reclaimed land to its owners [64].

In the period 1999-2010, the Romanian government, together with the World Bank, implemented two projects of mine closure and environmental and socioeconomic regeneration, which resulted in the rehabilitation of 51 closed mine sites: remediation of contaminated soils, stabilization of tailings dams and waste dumps and reclamation of more than 600 ha of mine land. Given that hundreds of mines were closed during the restructuring of the mining sector and that rehabilitation is a long process, the main objective of these projects was to build national capacities for similar operations on a large scale and in the long term.

There is no doubt that significant progress has been made in this regard, but there is still a lot of work, especially on hotspots requiring urgent action (e.g., Bosneag and Geamana tailings ponds), having in mind the accidents of the cyanide spill into the Tisa River in Baia Mare, 2000 [65]. In October 2014, the EC took Romania to the Luxembourg Court for failure to comply with EU mine waste legislation regarding the toxic Bosneag tailings pond in Moldova Noua. The Geamana tailings pond of Rosia Poieni copper mine threatens the water of the river Aries and through the rivers Mures, Tisa and Danube, risks cross-border pollution [66].

Pollution with dumps, decantation ponds, flotation tailings deposits, garbage deposits, etc., is the biggest threat to the environment and human health, both in the country and across borders. This type of pollution affects 6639 ha, mainly in Oltenia, of which 5773 ha is excessively affected. In the Bacau, Covasna, Gorj and Prahova counties, oil pollution is registered on 751 ha, of which 278 ha are heavily affected. Salt water (from oil extraction) pollution is registered on 2654 ha and strongly-excessive on 1205 ha. The areas affected by radioactive pollution amount to 566 ha and are located mainly in Brasov (500 ha) [67].

New mining projects draw particular attention regarding the environmental risks they cause. The Rosia Montana mining project comprises 300 ha covered by a tailings pond of cyanide, which will 
be used in the amount of 240 thousand tons in 17 years of exploitation. The Certej mining project requires two waste dumps, two tailings dams over 64 ha and the use of 26,448 tons of sodium cyanide and 15,280 tons of copper sulfate during the 16 years of operation.

Mine site rehabilitation has been integrated into the early planning process, even preceding the start of mine operations. Rehabilitation is an ongoing consideration throughout the mine's lifecycle, both from a technical and a financial standpoint [68].

The costs of land rehabilitation are classified as the mine's operating costs. According to Directive 2004/35/EC on environmental liability with regard to the prevention and remedying of environmental damage, the prevention and remedying of environmental damage should be implemented by applying the "polluter pays" principle, in line with the principle of sustainable development. Directive [24] on the management of waste from extractive industries and amending Directive [23] obliges operators to provide (and periodically adjust in size) a financial guarantee for waste facility maintenance and post-closure site restoration, including land rehabilitation.

The Serbian Law on Mining and Geological Research [69] only partially transposed Directive [24] on the management of waste from extractive industries. Disposal and management of mining waste is based on a permit for waste management, which is issued in accordance with the waste management plan. The operator is obliged to perform remediation and reclamation of degraded land during exploitation and after mining operations. Permanent cessation of mining operations is regulated by the main mining project for a permanent mine closure. The public mining companies are obliged to prepare a mine closure program, approved and financed by the government, which includes measures to address environmental and socio-economic consequences of the mine closure.

The draft of the Law on Amendments to the Law on Mining and Geological Research [70], which is under public debate, introduces the obligation for operators to ensure financial guarantees for rehabilitation and reclamation of mining fields.

The draft of the Law on Land Protection (2015) [71] obliges the land operator to remediate and/or reclaim degraded land (including land degraded by exploitation of minerals) using its own funds, according to the remediation and reclamation project, approved by departmental ministry. If the operator is unknown, inaccessible or does not comply with the legal provisions, the government finances the project, with the right of recourse of the costs from the operator. The law stipulates the obligation of land monitoring and keeping a register of contaminated sites. The analysis of the national legislative related to the transposition of Directive 2004/35/EC is still expected.

According to the Romanian Mining Law [72], the license holder has the following obligations related to land use and protection: to provide environmental agreements as one of the prerequisites for a building permit; to regularly update the mine closure plan; to set up and maintain the financial guarantee for environmental rehabilitation; and to execute and finalize the environmental rehabilitation of affected land in the mining site, according to the mine closure plan, including the post-closure monitoring program implementation and financing (in the case of state mining companies, these works, including abandoned mines, are financed by the state).

Apart from the Mining Law, the Government Decision (GD) [73], which transposes EU Directive [24] on the management of waste from extractive industries, as well as Government Emergency Ordinance [74], which implements the requirements of EU Directive 2004/35/CE on environmental liability, requests financial guarantees for waste facilities maintenance and for environment restoration 
in the case of pollution, respectively. In practice, there are problems in the calculation of the financial guarantee and the development of financial security instruments and markets as required by Directive [23], due to the lack of expertise in financial, economic and liability matters [75]. Mining companies are usually not required to set up a special guarantee for the waste facilities, but only to set up and maintain the financial guarantee regulated under the Mining Law [76].

It is obvious that both countries (especially Romania because of the structure of its mining sector) have serious environmental legacies, a lack of funds for their restoration and the need to strengthen the administrative capacity in this area, as well as the important tasks on harmonization and/or implementation of the EU mining waste legislation. Cooperation and joint engagement in applying for EU funds for addressing the most urgent mining environmental legacy issues would be of great benefit for sustainable development in the region.

\subsection{Mine Land Reclamation}

Mine sites, particularly large coal open pits, are usually returned to their pre-mine uses, primarily when prime farmland is mined, but where conditions for land restoration are poor, an adaptive management approach allows reclamation of disturbed land in line with different surrounding land uses and conditions [77-80]. The choice of reclamation method depends on geological, soil and climate conditions, the planned use of land (crop and ornamental plant production, forestry, wildlife habitats, water accumulations, infrastructural networks, sport and recreation objects, tourism and culture events, etc.), the phase of the mine lifetime and available technological solutions, equipment and financial resources [8]. There is evidence that the benefits of sustainable, multi-functional use of natural and semi-natural landscapes exceed the gains from their conversion to single-purpose land use types $[81,82]$. Rehabilitated mine sites should be able to take advantage of the existing infrastructure and contribute to the local economy after the mine has closed [83].

The largest area of land degraded by mining in Serbia and in Romania is located in lignite open pits. MB Kolubara covers 7.3 thousand ha, and it is planned to expand to a total of 13.4 thousand ha. The open pits and waste dumps of MB Kostolac cover 2.1 thousand ha [84]. In 2014, the total area of reclaimed land in MB Kolubara amounted to 915.5 ha, of which 790 ha is under forest, including lakes and ponds, and 125.5 ha under field crops and orchards. The cultivation of fast growing energy crops is also considered [85]. In MB Kostolac, until 2010, technical and biological reclamation (forest, field crops and vineyards) was accomplished on over 500 ha of degraded land. A nursery of trees and shrubs was also planted, and it is planned to raise a modern apple plantation [52].

According to the evaluation of land reclamation contained in the above-mentioned MB spatial plans, the results so far are modest. Reclamation did not lead to restoration of the previous agricultural and economic potentials of the land, which can be partly attributed to the complex issues of land ownership and land use of reclaimed land [86]. Reclaimed land is managed by a public company. Organizational weakness and a lack of financial resources result in high costs of reclamation and low profitability of production [85].

In the Romanian lignite open pits, according to preliminary data, a total of 24,432 ha was affected in 2013, most of it in the counties of Gorj (12,093 ha), Cluj (3915 ha) and Mehedinti (2315 ha). The reclamation of mine land with agricultural crops is considered the primary goal in most mine land 
reclamation programs [87]. In Gorj County, a total of 3333 ha was reclaimed, and 12,093 ha are arranged to be reclaimed; in Valcea County and Mehedinti County, 318 ha and 94 ha, respectively, are arranged, while 1074 ha and 466 ha, respectively, shall be reclaimed [67].

Land reclamation takes place in changed environmental, economic and social conditions in the local communities in both countries. It should, therefore, encourage multifunctional use of reclaimed land, adjusted to local conditions, in order to ensure full respect for complex ecosystem, economic and social functions of land as integrated natural resources [88].

\subsection{Land Access and Partnerships for Sustainable Mining}

Mineral resources and other geological resources in the Republic of Serbia, as well as in Romania are under state property. Mining rights in Serbia are transferred from the state to investors through approvals issued by the ministry upon the request of the commercial entity, i.e., another legal entity and entrepreneur. Mining rights in Romania are transferred from the state to investors through concession licenses (administration rights for public institutions). License holders acquire land for mining activities using general legal mechanisms, which include purchase, exchange, lease, concession, association with the owners and expropriation.

Land use conflicts between miners and private landholders reflect the problems in the way property rights to land and minerals are specified. Land ownership may theoretically assume the absolute title, but according to [89], Mattsson (2004, p. 143) argues that, in practice, absolute ownership rarely exists due to restrictions of various kinds. Explorers and miners may have certain rights of access to private land under state mining legislation [89].

Both the Serbian and Romanian government seek to establish adequate regulatory frameworks to enable more efficient use of mineral resources, respecting the needs to protect the public interest and attracting investments into the sector.

The Serbian draft of the Law on Amendments to the Law on Mining and Geological Research [70] nominates mineral resources of strategic importance for the Republic of Serbia (oil and natural gas, coal, copper and gold ores, ores of boron and lithium, oil shale and other mineral resources determined by a special act of the government). Detailed geological exploration and exploitation of these resources represent an activity of public interest. For the needs of the holders of exploration and mining rights, the competent authority may perform expropriation of property in accordance with the regulations governing the expropriation.

Expropriation in Romania has to be made in accordance with the Expropriation Law [90] for a public utility cause of national interest. As private projects are usually not considered in this sense, the application of this mechanism to obtain property rights over real estate for mining purposes is only theoretical [76]. However, in the draft of Law PL-x 573/2013 on amending the mining law, geological prospecting and exploration, as well as exploitation and processing of mineral resources are declared as public utility works. Such categorization of mining works, which entails expropriation and the provision of some other extraordinary powers to investors (the exemption of some permitting procedures related to works on archaeological sites, reissuing of permits cancelled by courts, etc.), was sharply criticized by the public, up to charges of the violation of constitutional rights. 
The distribution of mining royalties is another issue that causes anxiety and resistance in the local community, but also controversy among experts from civil society.

The revenues from mining royalties in Serbia are directed to the state budget $(40 \%)$, the budget of local authorities (40\%), the provincial budget 10\% (if the exploitation is performed on the territory of the province) and to the departmental ministry funds $(20 \%$ or $10 \%$ if the exploitation takes place on the territory of the province). These funds are used for the elimination of the harmful impacts of mining and mining development promotion (national level) and for improving living conditions and infrastructure (local community) [69].

Mining royalties in Romania are directed to the state budget. One of the amendments to the Mining Law (draft of Law PL-x 573/2013) refers to the transfer of a part of mining royalties to the local authorities in the mining areas for infrastructure development and environmental rehabilitation. According to critics, such a mechanism would undermine the application of the "polluter pays" principle, transposed in the environmental protection legislation and in the Mining law [72].

As stated in the Introduction, the partnerships of industry, governments, local communities and civil society are essential to maintain and manage shared-value opportunities [14]. Through a public review process, the local communities in Serbia are present in the development of spatial and urban plans for the areas with the possibility for exploitation of mineral resources. Compliance with these documents is part of the exploration and mine permitting process. However, a broad public debate, which was recently conducted in Serbia related to nickel exploration, has exposed their dissatisfaction with the role they have in the decision-making process [91].

The procedures for providing environmental agreements (Environmental Impact Assessment_EIA, Strategic Environmental Assessment-SEA) in Romania envisage public debate and cross-border consultations, but public opinion is not mandatory for the environmental authorities [76]. However, the above-mentioned draft law PL-x 573/2013 failed to receive a majority vote in the parliament, as well as some other special laws with most of these provisions, after strong public resistance [43]. Foreign investors are still waiting for a more transparent, simplified and predictable regulatory framework for mining operations, and the government is looking for the best legal updates that will ensure majority support on these sensitive issues.

As Cutifani and Bryant [26] stressed, mining companies must understand that they can no longer operate in isolation; rather, the mining industry can only thrive into the long term if local communities and the local environment thrive. They have to anticipate their challenges into the future and move away from a short-term reactive approach embedded in "survival" to a long-term philosophy beyond the life of a mine that articulates clear, common goals to creating shared value and that provides the infrastructure to make this a reality.

\section{Concluding Remarks}

Both analyzed countries, Serbia and Romania, have experienced a mineral policy, regulation and business models of state-owned mining companies in socialism, when strengthening the national economy had precedence over environmental protection and property rights in local communities. Even more devastating ecological and social consequences have occurred in the period of transition, burdened by financial crisis, undeveloped institutions, non-harmonized legislation and corruption. Two decades 
later, both governments are willing to provide the adequate role to mining in strengthening the national economies, but new challenges place new sustainability demands before all of the stakeholders in the mining sector.

There must be clear legal relations between the state as the owner of natural resources, the investors and the land owners and other stakeholders affected by the exploration and mining. Sustainable spatial, regional and mineral policies, taking the environmental and economic evaluation of space, must be able to provide answers where and when it is or is not appropriate to mine. A transparent business policy of mining companies and their acceptance of the role of a regional development partner, ready to maintain and manage shared value, will contribute towards a consensus in mutual benefit.

Particular attention should be devoted to land expropriation and rehabilitation in order to help create a positive public opinion on the acceptance of mining activities, particularly in densely-populated areas with developed agriculture, respecting the FAO SLM principles of land user-driven and participatory approaches, integrated the use of natural resources at the ecosystem and farming system levels and targeted policy and institutional support to income generation at the local level.

Sustainable mining practice and consistent implementation of the mine closure planning approach require a developed partnership of mining companies, spatial planners, investors, institutions and local communities to identify creative, profitable, environmentally-sound and socially-responsible management and reuse of mine lands.

Transnational and, in particular, cross-border cooperation between countries in the Danube River Basin is extremely important, bearing in mind the transnational risks of large mining environmental hotspots in both countries. The accident of the cyanide spill into the river Tisa from the gold mines in northern Romania (2000) left behind an ecological disaster and long-term consequences for the ecosystems in Romania, Hungary and Serbia. Continuous inventory and risk assessment, information exchange, joint control and early warnings are priorities in this area.

Since both countries are signatories of the Danube River Protection Convention (DRPC), Romania is an EU member and Serbia a candidate for membership in the EU, there are significant opportunities for cooperation and joint engagement in applying for EU funds for addressing the most urgent mining environmental legacy issues.

\section{Acknowledgments}

The paper was prepared within the scientific projects: Sustainable agriculture and rural development in the function of accomplishing strategic objectives of the Republic of Serbia in the Danube region (III 46006) and Sustainable spatial development of the Danube region in Serbia (TR 36036), financed by the Ministry of Education, Science and Technological Development of the Republic of Serbia in the period 2011-2015. Furthermore, the authors would like to thank the reviewers for their valuable comments and suggestions, which helped strengthen this paper.

\section{Author Contributions}

Vesna Popović contributed to the chapters about mine land management in legislation and practice in Serbia, land access and partnerships for sustainable mining and concluding remarks; Jelena Živanović Miljković contributed to the chapters about mine land change, mining waste management and mine land 
reclamation in Serbia, Jonel Subić wrote Introduction chapter and contributed to concluding remarks; Andrei Jean-Vasile, Nedelcu Adrian and Eugen Nicolăescu wrote about mine land management in legislation and practice in Romania, mine land change, mining waste management, mine land reclamation and partnerships for sustainable mining in Romania. All authors read and approved the final manuscript.

\section{Conflicts of Interest}

The authors declare no conflict of interest.

\section{References and Notes}

1. FAO. Land Evaluation. Towards a Revised Framework; Land and Water Discussion Paper 6; FAO: Rome, Italy, 2007.

2. Brundtland, G.H. Our Common Future. Report of the World Commission on Environment and Development; Oxford University Press: Oxford, UK, 1987.

3. Smyth, A.J.; Dumanski, J. FESLM: An International Framework for Evaluating Sustainable Land Management. World Soil Resources Report; FAO: Rome, Italy, 1993; p. 73.

4. UN. The Future We Want: Outcome document adopted at Rio+20, 2012. Available online: http://www.uncsd2012.org/content/documents/727The\%20Future\%20We\%20Want\%2019\%20Ju ne\%201230pm.pdf (accessed on 12 April 2015).

5. European Commission. Communication from the Commission to the European Parliament, the Council, The European Economic and Social Committee and the Committee of the Regions. Roadmap to a Resource Efficient Europe. Brussels, 20.9.2011, COM(2011) 571 final.

6. European Commission. Communication from the Commission. EUROPE 2020-A strategy for smart, sustainable and inclusive growth. Brussels, 3.3.2010, COM(2010) 2020 final.

7. European Commission. Study Supporting Potential Land and Soil Targets under the 2014 Land Communication. Final Report; EU: Luxembourg, 2014.

8. Spasić, N.; Stojanović, B.; Nikolić, M. Environmental impact of the mining activity and revitalization of degraded space. Arhit. Urban. 2005, 16-17, 75-85.

9. Sonter, L.J.; Barrett, D.J.; Soares-Filho, B.S. Offsetting the impacts of mining to achieve no-net-loss of native vegetation. Conserv. Biol. 2014, 28, 1068-1076.

10. Sonter, L.J.; Moran, C.J.; Barrett, D.J. Modeling the impact of revegetation on regional water quality: A collective approach to manage the cumulative impacts of mining in the Bowen Basin, Australia. Resour. Policy 2013, 38, 670-677.

11. Sonter, L.J.; Morgan, C.J.; Barrett, D.J.; Soares-Filho, B.S. Processes of land use change in mining regions. J. Clean. Prod. 2014, 84, 494-501.

12. Hobbs, J.C.A. Enhancing the contribution of mining to sustainable development. Geol. Soc. 2005, 250, 9-23.

13. Buxton, A. MMSD+10: Reflecting on a Decade. IIED Discussion Paper; International Institute for Environment and Development: London, UK, 2012.

14. Bartels, R.; Garcia, J.; Reynolds, O.; Thimmiah, S.; Tost, M.; Wong, A. Scoping Paper: Mining and Metals in a Sustainable World. In Proceedings of the World Economic Forum Mining \& Metals Industry Partnership in Collaboration with Accenture, Geneva, Switzerland, 12-18 February 2014. 
15. International Council on Mining \& Metals-ICMM. Mining's contribution to sustainable development—An overview, 2012. Available online: https://www.icmm.com/document/3716 (accessed on 4 July 2015).

16. Esteves, A.M.; Franks, D.; Vanclay, F. Social impact assessment: The state of the art. Impact Assess. Proj. Apprais. 2012, 30, 34-42.

17. Franks, D. Social impact assessment of resource projects. International Mining for Development Centre Mining for Development: Guide to Australian Practice, 2012. Available online http://im4dc.org/wp-content/uploads/012/01/UWA_1698_Paper-02_Social-impact-assessment-ofresource-projects1.pdf (accessed on 28 June 2015).

18. Franks, D.M.; Vanclay, F. Social Impact Management Plans: Innovation in corporate and public policy. Environ. Impact Assess. Rev. 2013, 43, 40-48.

19. Athens Declaration on sustainable access to resources - Critical Raw Materials, Minerals Policy, Land-Use Planning and Permitting. Available online: http://www.euromines.org/files/news/ importance-extractive-industry-growth-eu/final-version-athens-declaration-20june2014.pdf (accessed on 3 May 2015).

20. Shields, D.J.; Šolar, S.V. Sustainable Mineral Resource Management and Indicators: Case Study Slovenia; Geological Survey of Slovenia: Ljubljana, Slovenia, 2004.

21. Shields, D.J.; Šolar, S.V.; Martin, W.E. The role of values and objectives in communicating indicators of sustainability. Ecol. Indic. 2002, 2, 149-160.

22. Grantam, J.; Owens, C.; Davies, E. Improving framework conditions for extracting minerals for the EU: Exchanging best practice on land use planning, permiting and geological knowledge sharing. Available online: http://ec.europa.eu/enterprise/policies/raw-materials/files/best-practices/ sust-full-report_en.pdf (accessed on 28 June 2015).

23. Directive 2004/35/CE of the European Parliament and of the Council on environmental liability with regard to the prevention and remedying of environmental damage, OJ L 143, 30.4.2004.

24. Directive 2006/21/EC of the European Parliament and of the Council on the management of waste from extractive industries and amending Directive 2004/35/EC, OJ L 102, 11.4.2006.

25. Wang, U. Sustainable mining: An inherent contradiction in terms? Available online: http://www.theguardian.com/sustainable-business/2015/jan/05/sustainable-mining-business-povertyenvironment-new-framework (accessed on 10 July 2015).

26. Cutifani, M.; Bryant, P. Reinventing Mining: Creating Sustainable Value-Introducing the Development Partner Framework. Kellogg Innovation Network, 2014. Available online: http://sustainbusiness.org/PDF/DevelopmentPartnerFramework.pdf (accessed on 10 July 2015).

27. UN. Environmental Performance Reviews-Romania. Second Review. Environmental Performance Reviews Series; UNECE: New York, NY, USA; Geneva, Switzerland, 2012; p. 37.

28. European Commission. Report on Critical Raw Materials for the EU; DG-ENTR: Brussels, Belgium, 2014.

29. Stanojević, J. To more foreign investors by the new law. Available online: http://www.rtb.rs/media/kolektiv/2258.pdf (accessed on 11 August 2015).

30. Government of the Republic of Serbia. Strategy of Mineral Resources Management by 2030 (Draft); National Assembly: Belgrade, Serbia, 2012. Available online: http://www.srbija.gov.rs/ vesti/dokumenti_sekcija.php?id=45678 (accessed on 11 August 2015). 
31. Ricketts, B. (Ed.) Coal Industry across Europe, 5th ed.; European Association for Coal and Lignite-Euracoal: Brussels, Belgium, 2013.

32. Official Gazette of the Republic of Serbia. Decision on setting the Energy Balance of the Republic of Serbia for 2015. Available online: http:/www.slglasnik.info/sr/147-31-12-2014.html (accessed on 27 May 2015).

33. RTB Bor Group. Resources. Available online: http://rtb.rs/en/ (accessed on 7 July 2015).

34. Magdalinović, N. Situation and prospects of mineral processing in Serbia. In Proceedings of the Roundtable Condition and Prospects of Mineral Processing in Serbia, Belgrade, Serbia, 17-22 April 2011.

35. Reichl, C.; Schatz, M.; Zsak, G. Minerals Production, 29; World-Mining-Data: Vienna, Austria, 2014.

36. Radut, C. Romania's oil and gas reserves. Available online: http://www.nineoclock.ro/ romania $\%$ E2\%80\%99s-oil-and-gas-reserves/ (accessed on 24 February 2015).

37. U.S. Energy Information Administration-EIA. Technically Recoverable Shale Oil and Shale Gas Resources. Available online: http:/www.eia.gov/analysis/studies/worldshalegas/pdf/ fullreport.pdf?zscb=60747969 (accessed on 29 May 2015).

38. Zittel, W. Fracking: Interim Report; Energy Watch Group: Berlin, Germany, 2015. Available online: http://energywatchgroup.org/new-energy-watch-group-study-end-fracking-business/ (accessed on 29 May 2015).

39. Nutu, O.; Ivan, V.; Ondrich, J.; Bebiak, M. Cost of Coal to Romania. The Cost of Subsidies Received by Romanian Coal Industry in Comparison with Renewable Industry; Candole Partners: Bucharest, Romania, 2014. Available online: http://www.candole.com/research (accessed on 28 May 2015).

40. Council Decision 2010/787/EU on State aid to facilitate the closure of uncompetitive coal mines, OJ L 336, 21.12.2010.

41. Cupru Min. The main activity of S.C. CUPRU MIN S.A. Abrud. Available online: http://www.cuprumin.ro/en/despre.htm (accessed on 11 June 2015).

42. UN. Environmental Performance Reviews-Romania; UNECE: New York, NY, USA; Geneva, Switzerland, 2001.

43. Pencea, R.; Bradatan, T.; Simion, Ş. Transylvania-Undermined Territory; Mining Watch Romania: Cluj-Napoca, Romania, 2013. Available online: http://www.academia.edu/10230358/ Romania_-_a_mined_field (accessed on 28 May 2015).

44. Stroe, D. Romania to start a new uranium extraction project. Available online: http://www.balkaneu.com/romania-start-uranium-extraction-project/\#sthash.NNf2qgf1.dpuf (accessed on 22 May 2015).

45. National Institute of Statistics of Romania. Romanian Statistical Yearbook 2012. Available online: http://www.insse.ro/cms/files/Anuar\%20arhive/serii\%20de\%20date/2012/pdf/ASR\%202012_rom.pdf (accessed on 24 May 2015).

46. Peck, P.; Stuhlberger, C.; Simonett, O.; Williams, S. Mining in the Western Balkans. In Mining and Environment in the Western Balkans; Stuhlberger, C., Ed.; UNEP: Vienna, Austria, 2010; pp. 41-90.

47. Noble, B.F. Introduction to Environmental Impact Assessment: A Guide to Principles and Practice; Oxford University Press: Oxford, UK, 2006. 
48. Sassoon, M. Financial Surety: Guidelines for the Implementation of Financial Surety for Mine Closure; Extractive Industries for Development Series, World Bank, Oil, Gas, and Mining Policy Division: Washington, DC, USA, 2009; p. 7. Available online: http://siteresources.worldbank.org/ INTOGMC/Resources/7_eifd_financial_surety.pdf (accessed on 12 May 2015).

49. Mitchell, P. Mining and economic growth: The case for Ghana and Tanzania. South Afr. J. Int. Aff. 2006, 13, 55-67.

50. Schueler, V.; Kuemmerle, T.; Schroder, H. Impacts of Surface Gold Mining on Land Use Systems in Western Ghana. Ambio 2011, 40, 528-539.

51. Institute of Architecture and Urban\&Spatial Planning of Serbia (IAUS). Amendments on the Spatial Plan for the Exploitation Area of Kolubara Lignite Basin. Internal Documentation Material; IAUS: Belgrade, Serbia, 2015.

52. Official Gazette of the Republic of Serbia. Spatial plan for the Kostolac mining basin Special-Purpose Area. Available online: http://www.rapp.gov.rs/rudarski-baseni/cid296-83227/prostorni-plan-podrucjaposebne-namene-kostolackog-ugljenog-basena (accessed on 11 May 2015).

53. University of Belgrade, Faculty of Mining and Geology. Strategy of Coal Mineral Resources Management in Kolubara i Kostolac Basins for the Period until 2017, Documentation Materials; Faculty of Mining and Geology: Belgrade, Serbia, 2012.

54. Mining Journal. Better times to come. Focus: East-Central Europe. Available online: http://www.euromines.org/files/publications/mining-journal-feature-july-2014-east-central-europe.pdf (accessed on 14 May 2015).

55. Mining Watch Romania. Under Action: Certej, Baita Craciunesti, Baia Mare, Rosia Montana. Available online: http://miningwatch.ro/certej/?lang=en (accessed on 7 July 2015).

56. Official Gazette of the Republic of Serbia. Spatial plan of Kolubara lignite basin area. Available online: http://www.rapp.gov.rs/rudarski-baseni/cid296-83173/prostorni-plan-podrucja-eksploatacijekolubarskog-lignitskog-basena (accessed on 11 May 2015).

57. European Commission-DG Environment. Mining Waste, 2015. Available online: http://ec.europa.eu/environment/waste/mining/ (accessed on 7 June 2015).

58. Lottermoser, B. Mine Wastes: Characterization, Treatment and Environmental Impacts; Springer: New York, NY, USA, 2012.

59. Edraki, M.; Baumgartl, T.; Manlapig, E.; Bradshaw, D.; Franks, D.M.; Moran, C.J. Designing mine tailings for better environmental, social and economic outcomes: A review of alternative approaches. J. Clean. Prod. 2014, 84, 411-420.

60. Franks, D.M.; Boger, D.V.; Cote, K.M.; Muligan, D.R. Sustainable development principles for the disposal of mining and mineral processing wastes. Resour. Policy 2011, 36, 114-122.

61. Blic. In Vojvodina, 217 abandoned mining pits, 2015. Available online: http://www.blic.rs/ Vesti/Vojvodina/570603/U-Vojvodini-217-napustenih-rudarskih-kopova (accessed on 7 July 2015).

62. Peck, P. Reducing Environment \& Security Risks from Mining in South Eastern Europe. Desk-assessment study for the Environment and Security Initiative Project. Available online: http://www.envsec.org/publications/Reducing\%20environment $\% 20$ and $\% 20$ security $\% 20$ risks $\% 20 \mathrm{f}$ rom\%20mining\%20in\%20SEE.\%20Desk\%20assessment\%20study.pdf (accessed on 11 June 2015).

63. Bogdanović, G.; Trumić, M.; Antić, D.V. Mining waste management: Genesis and possibility of processing. Reciklaža Održivi Razvoj 2011, 4, 37-43. 
64. Živanović, M. Vojvodina's municipalities and villages are complaining about the NIS. Vojvodina Research and Analytical Center-VOICE. Available online: http://voice.org.rs/ voice-vojvodanske-opstine-i-sela-se-zale-na-nis/ (accessed on 22 March 2015).

65. Pencea, R.; Bradatan, T.; Simion, S. Baia Mare-Avanpremiera dezastrului provocat de industria miniera. Mining Watch Romania. Available online: http://miningwatch.ro/wp-content/ uploads/2014/01/Raport BaiaMare-MiningWatchRomania.pdf (accessed on 7 July 2015).

66. Besliu, R. Romania's unsolved communist ecological disaster. OpenDemocracy. Available online: https://www.opendemocracy.net/countries/romania (accessed on 19 March 2015).

67. Ministry of Environment and Climate Changes of Romania. National Environmental Protection Agency, National Report on the State of Environment in 2013; ANPM: Bucharest, Romania, 2014. Available online: http://www.anpm.ro/raport-de-mediu (accessed on 30 May 2015).

68. Minalliance. 100 Innovations in the Mining Industry; PDAC and The Mining Association of Canada: Montreal, QC, Canada, 2012. Available online: http:/www.oma.on.ca/en/ontariomining/ resources/Minalliance_100_innovations_en.pdf (accessed on 17 May 2015).

69. Official Gazette of the Republic of Serbia. Law on Mining and Geological Research. Available online: http://www.en.terragold.co.rs/Laws/LAW-ON-MINING-AND-GEOLOGICALEXPLORATION.pdf (accessed on 28 May 2015).

70. Ministry of Mining and Energy of the Republic of Serbia. Draft of Law on Amendments to the Law on Mining and Geological Research, 2015. Available online: http://www.mre.gov.rs/javnerasprave.php (accessed on 18 May 2015).

71. Ministry of Agriculture and Environmental Protection of the Republic of Serbia. Draft of Law on Land Protection, 2015. Available online: http://www.eko.minpolj.gov.rs/dokumenti/ (accessed on 18 May 2015).

72. Official Gazette of Romania. Mining Law no. 85/2003. Available online: http://www.mpo.cz/ kalendar/ download/71546/priloha003.pdf (accessed on 5 June 2015).

73. The Government of Romania. Decision no. 856/2008 on the management of waste from extractive industries. Available online: http://lege5.ro/en/Gratuit/geytgobygi/hotararea-nr-856-2008-privindgestionarea-deseurilor-din-industriile-extractive (accessed on 4 June 2015).

74. The Government of Romania. Emergency Ordinance no. 68/2007 on environmental liability with regard to the prevention and remedying of environmental damage. Available online: http://lege5.ro/en/ Gratuit/geydqobvgm/ordonanta-de-urgenta-nr-68-2007-privind-raspunderea-de-mediu-cu-referirela-prevenirea-si-repararea-prejudiciului-asupra-mediului (accessed on 4 June 2015).

75. Permanent Representation of Romania to the EU. Report on the implementation of the Directive 2004/35/EC on environmental liability, Brussels, 2013, 3508. Available online: http://ec.europa.eu/ environment/legal/liability/pdf/eld_ms_reports/RO.pdf (accessed on 29 May 2015).

76. Dragomir, C.; Halcu, B. Romania. In The Mining Law Review, 3rd ed.; la Fleche, E.R., Ed.; Law Business Research Ltd.: London, UK, 2014; pp. 242-252.

77. Bowman, B.; Baker, D. Mine Reclamation Planning in the Canadian North. Northern Minerals Program; Working Paper no.1; Canadian Arctic Resources Committee: Ottawa, ON, Canada, 1998.

78. Doley, D.; Audet, P. Adopting novel ecosystems as suitable rehabilitation alternatives for former mine sites. Ecol. Process. 2013, 2, 1-11. 
79. Limpitlaw, D.; Briel, A. Post-mining land use opportunities in developing countries-A review. J. South. Afr. Inst. Min. Metall. 2014, 114, 899-903.

80. Minerals Education Coalition-MEC. Reclamation Stories-Coal, 2015. Available online: https://www.mineralseducationcoalition.org/reclamation-stories/coal (accessed on 2 July 2015).

81. De Groot, R. Function-analysis and valuation as a tool to assess land use conflicts in planning for sustainable, multi-functional landscapes. Landsc. Urban Plan. 2006, 75, 175-186.

82. Zhang, J.; Fu, M.; Hassani, F.P.; Zeng, H.; Geng, Y.; Bai, Z. Land Use-Based Landscape Planning and Restoration in Mine Closure Areas, Environ. Manag. 2011, 47, 739-750.

83. Dutta, S.; Rajaram, R.; Robinson, B. Mineland Reclamation. In Sustainable Mining Practices-A Global Perspective; Rajaram, V., Dutta, S., Eds.; A.A. Balkema Publishers: Leiden, The Netherlands, 2005; pp. 179-191.

84. Serbian Environmental Protection Agency. The Report on the Status of Land in the Republic of Serbia for 2011; SEPA: Belgrade, Serbia, 2012.

85. Kolubara, M.B. Report on the State of the Environment in 2014; Sector for Environmental Protection and Enhancement: Lazarevac, Serbia, 2015. Available online: http://www. rbkolubara.rs/ index.php?option $=$ com_content\&view $=$ article\&id=470\&Itemid $=225 \&$ lang $=$ en $\quad($ accessed on 12 May 2015).

86. Popović, V.; Živanović Miljković, J. Key issues of land policy in Serbia in the context of spatial development - Case study of Danube basin area. In Proceedings of 2nd International Scientific Conference Regional development, spatial planning and strategic governance (RESPAG 2013), 22-25 May 2013; Vujošević, M., Milijić, S., Eds.; IAUS: Belgrade, Serbia, 2013; pp. 271-297.

87. Dumitru, E.; Popescu, A. Reclamation on Land Disturbed by Surface Mining in Romania. Available online: http://www.asmr.us/Publications/Conference\%20Proceedings/2002/0115\%20Dumitru.pdf (accessed on 23 May 2015).

88. Popović, V.; Nikolić, M.; Katić, B. Agricultural Land Use and Protection in Serbia; Institute of Agricultural Economics: Belgrade, Serbia, 2011.

89. Jonson, L.E. Mineral Rights. Legal Systems Governing Exploration and Exploitation. Ph.D. Thesis, School of Architecture and the Built Environment, Royal Institute of Technology (KTH), Stockholm, Sweden, 2010. Available online: http://nickelmountain.se/wp-content/uploads/2014/ 01/Mineral-rights-Legal-Systems-Governing-Exploration-and-Exploitation.pdf (accessed on 15 July 2015).

90. The Parliament of Romania. Law no. 33/1994 on the expropriation for public utility. Available online: http://lege5.ro/en/Gratuit/gi2tqnbtgi/legea-nr-33-1994-privind-exproprierea-pentru-cauza-de-utilitatepublica (accessed on 14 May 2015).

91. Center for Democracy and Germany's Friedrich Ebert Foundation. Nickel: Economic benefits and environmental risks. Debate. Available online: http://www.dc.politickiforum.org/ index.php?vrsta=tribina\&naredba $=$ prikaz\&tekst $=80$ (accessed on 8 November 2012).

(C) 2015 by the authors; licensee MDPI, Basel, Switzerland. This article is an open access article distributed under the terms and conditions of the Creative Commons Attribution license (http://creativecommons.org/licenses/by/4.0/). 